\title{
Political indoctrination through myth building: The New Zealand School Journal at the time of World War 1
}

\author{
Carol Mutch, Rosemary Bingham, Lynette Kingsbury, \\ and Maria Perreau \\ https://doi.org/10.18296/cm.0031
}

\begin{abstract}
As the commemorations of the 100th anniversary of World War 1 draw to a close, it is timely to reflect on what we have learnt about that time in our history. This study used the New Zealand School Journal as a data source to investigate what school children were learning about the war at the time. In this article, we discuss the overt and covert messages that New Zealand school children were given about their relationship, first, to the British Empire and, second, to a new distinct New Zealand identity. The World War 1 acts as a pivot point from which to examine the change from myths surrounding the British Empire to a new set of myths springing from the Gallipoli campaign. Our analysis of the School Journal at this time highlights the possible ways in which curricula and curriculum resources can be manipulated and used for political indoctrination.
\end{abstract}

\section{Introduction}

Since 2014, New Zealand has been commemorating the 100th anniversary of World War 1. A plethora of news items, magazine articles, books, films, documentaries, and teaching resources has been published to coincide with the commemorations (see, Mutch \& Cameron-Lewis, 2017). It has been hard to separate the facts from the hype. The long-held view of the Gallipoli campaign forging a new New Zealand identity endures alongside that of the brave Anzac soldier who epitomised the best of New Zealand manhood (Bingham, 2017; Carlyon, 2011; Eldred-Grigg, 2010; King, 2007; Mutch \& Cameron-Lewis, 2017; Phillips, 1996; Pugsley, 1990). The statistics, however, tell a darker story-that approximately one in 10 New Zealanders went to war and, of those, one in four died or was seriously injured (Phillips, 1996). 
In 2014, we sought funding to use early issues of the New Zealand School Journal as source material to examine the way in which the war was portrayed to school children of the day as part of a wider study titled, "Teaching about war: Yesterday and today" (see Mutch, 2017). In this article, we discuss the overt and covert messages contained within the School Journals contents. We found that, from as early as 1907, when the School Journal was first launched, children were fed a steady diet of rhetoric that exhorted them to be loyal and dutiful citizens of the British Empire and for whom there was no greater glory than self-sacrifice. When war was declared in 1914, some of the younger men who signed up would already have been primed to serve the Empire through their classroom reading material. As the war proceeded, reports in the School Journal continued the themes of courage, honour, heroism, and self-sacrifice despite the horrific toll that the war was taking. We observed, however, in the late 1920s, a shift in the School Journal from the pre-war rhetoric of duty to the Empire to New Zealand forging its own mythological rhetoric. The findings from our study serve to highlight the ways in which curricula and curriculum resources can be manipulated, knowingly or unknowingly, by those in power for political purposes.

\section{The New Zealand School Journal}

The New Zealand School Journal was established in 1907 to provide reading material in support of the newly reformed primary school curriculum. Initiated by the-then Inspector-General of Schools, George Hogben, the School Journal was published with the aim of providing curriculum content reflective of New Zealand children's interests and experiences (Hucker, 1979; Malone, 1973; O'Brien, 2007). In 1914, it was made compulsory reading material in state schools (Malone, 1973). As the Department of Education's only publication for children until 1939, the School Journal has had a wide influence on the education of New Zealand children over many decades (Malone, 1973; O’Brien, 2007).

Hogben, a liberal imperialist, who believed the Empire to be a civilising force with a high moral duty, saw education as an instrument of social change. Ideals of strength and moral virtue were attainable through discipline, obedience, and self-sacrifice. His reforms aligned with new educational movements that aimed to foster in school children a love and attachment to their country, beginning with the local and familiar and expanding 
outwards to the development of an imperial patriotic spirit (Malone, 1973; Patrick, 2009). The School Journal was tasked with this imperative. The first edition was published on 9 May 1907. It was a multi-subject journal, focusing on literature, history, geography, civics, moral instruction, science, and health. It was provided at three age levels and published monthly from May to November (and from February to November from 1908 onwards). Content included nonfiction, fiction, poetry, photographs, and illustrations. The journals were provided free to all children in state-funded schools or at a minimal cost to those in private schools. Children each had their own copy which they could use in the classroom and later take home. November issues were larger than usual, so children could continue reading over the Christmas holidays (Ewing, 1970; O’Brien, 2007).

\section{Study context and theory}

With the anniversary of World War 1 having recently taken centre stage in New Zealand currently, it is timely to reflect on the events, how they were portrayed at the time, and how we view them with hindsight. The year 2015 marked the centenary of the landing of the Australian and New Zealand Army Corps on the Gallipoli Peninsula, where the legend of the rugged and heroic Anzac figure was born, and November 2018 marked the anniversary of the signing of the Armistice. It is in the context of the anniversary commemorations that this School Journal project was undertaken.

Our study examined how World War 1 was portrayed to New Zealand primary school children, through their main cross-curricular resource, the School Journal. As a significant adjunct to the prescribed curriculum, the School Journal provides a rich source of information on the values and perspectives of the times. We view the early School Journal as an historically situated, socially constructed, and politically infused curriculum artefact. Our approach to curriculum is consistent with many curriculum scholars who look beyond policy and prescription to view curriculum as a multilayered and contested concept (Apple, 1979; Kridel, 2013; Mutch, 2009; Pinar, Reynolds, Slattery, \& Taubman, 1995). Our particular interest is in how the curriculum of the day is interpreted and disseminated in curriculum resources, such as the School Journal, and, in this case, how it reflects the political ideologies of the time. 
While it could be argued that a country's curriculum and its accompanying content resources, such as textbooks, should reflect the society of the day, many historians and curriculum theorists argue that curriculum materials are not neutral. They ask, "What content is selected, by whom, and whose interests are being served?” (Apple, 1979; Foster \& Crawford, 2006; Kridel, 2013; Pinar et al., 1995). To answer these questions, researchers have gone on to examine curriculum texts and resources more closely, exposing censorship, propaganda, and political indoctrination (see, for example, Foster \& Crawford, 2006; Kridel, 2013; Matusevich, 2006). Their findings highlight what is called, in curriculum terms, the hidden or null curriculum (Apple, 1979; Kridel, 2013; Pinar et al., 1995).

Propaganda and indoctrination are contested terms (Kridel, 2013; Peterson, 2007). Kridel (2013) claims that propaganda in education has no precise definition because it is very situational. He states, "Any act of selecting curricular experiences involves some form of the imposition of values" (p.163) and could include instruction, indoctrination, or hegemony. The use of propaganda in education is not something existing only in the past. It is present today through the commercialisation of education, in which the public and schools have become complicit. In contrast to propaganda, Kridel suggests, "indoctrination often represents a more one-directional focused act that serves to 'foster' ideology and/or to punish non-acceptance" (2013, p. 164). Peterson (2007) puts the responsibility for indoctrination on the teacher-stating that indoctrination is the result of particular content, taught in particular ways to lead to particular outcomes; that is, to get students to hold beliefs in a nonrational and noncritical manner. Snook (1972) claims that for teaching to be indoctrination, there must be intent, or the desire to get students to hold these beliefs regardless of evidence to the contrary. Foster and Crawford (2006) hold the curriculum more responsible, describing it as a battleground in which interested parties battle for domination over what is legitimate content. Matusevich (2006) also includes curriculum resources, particularly mandated textbooks, as sites of contestation, where officials engage knowingly in indoctrination and censorship.

Political indoctrination is a loaded concept with mostly negative connotations (Callan \& Arena, 2009). It is often associated with former totalitarian regimes, such as Hitler’s Germany (Callan \& Arena, 2009) or Franco’s Spain (Mahamud, 
2016). An examination of the field reveals many examples on the negative side of the ledger. Lall (2008) investigated the way in which government authorities in both India and Pakistan each rewrote their curricula to position the other country as antagonistic; Burdman (2003) examined the way in which Palestinian children were indoctrinated with the idea of martyrdom; Nelson (2015) explored the way in which Putin's regime rehabilitated the image of Stalin in contemporary Russian high-school textbooks; Lee (2010) researched the way non-North Koreans, particularly Americans, are portrayed in North Korean textbooks. The list could go on. Powerful elites-individuals or organisations - can and do manipulate the curriculum and curriculum resources for political ends. This study returns to an important time in New Zealand history and examines a curriculum resource used widely in classrooms to examine the way in which political indoctrination was used in subtle and unsubtle ways to foster in children a particular view of World War 1.

\section{Study methods}

After deciding on the School Journal as the data source that would provide rich insight into what most children of the time were reading, we then had to locate the relevant copies. After making inquiries, we found the Sylvia Ashton Warner library on The University of Auckland's Epsom Campus had the most comprehensive set. Because of the fragile nature of these early copies, we were not allowed to borrow, read, or photocopy the originals. We were lucky to get the support of a senior librarian at the university's central library and, through him, arrange inter-campus loans. At the central library, we were able to access a state-of-the-art archival scanner to make word-searchable copies.

Each scanned School Journal issue between 1907 and 1930 (over 500 in all) was read, searched, and reviewed for emerging themes. Details were entered into a shared Google Docs database, which provided bibliographic data, descriptive summaries of text and images, and emerging qualitative analyses available to all researchers engaged in the larger project. Data relating to content, themes, type of text, year of publication, class level, and relationship to other items were synthesised and categorised. Once a strong theme was identified, researchers could access both original data and summary tables to develop their ideas (see, for example, Bingham, 2017; Perreau \& Kingsbury, 
2017). The database of word-searchable scanned copies of the School Journal (now up to the year 1985) remains available to other researchers at The University of Auckland through a restricted library portal.

This article draws on analyses of written and visual items in the early years of the School Journal. It discusses how nonfiction and fiction stories, poems, and illustrations were presented to reinforce moral and political messages. The findings, from loyalty to the British Empire to the emergence of nationhood at the time of World War 1, are set out in two parts. Part 1 is the pre-war stage, which, in hindsight, seems eerily prescient. Part 2 focuses on the reporting of the war and post-war commemorations.

\section{Findings Part 1-Pre-war: Preparing the citizens of the Empire for war}

There are several themes that occur regularly across the year levels in relation to preparation for war. The first theme is the inculcation of a particular set of values and behaviours, in particular, duty, courage, and self-sacrifice, through stories, poems, and role models. The second is the importance of the British Empire and the expectation that New Zealand citizens will be dutiful and loyal to the Empire. The third theme is the valorisation of war and those who take part.

\section{Children as good citizens of the Empire}

The School Journal offered the opportunity to provide regular and consistent messages about appropriate character traits and behaviours expected of the children of New Zealand and the Empire. Younger children are exhorted to be good, kind, obedient, and to always do their best:

Do your best, your very best,

And do it every day,

Little boys and girls:

That is the wisest way. [1907/1/6/p. 92 $]^{1}$

1 References to the particular issues are given in the following manner: [Year/Part/ Number/Page(s)]. Part 1 journals were for Classes 1 and 2 (5-6 year olds); Part 2 for Classes 3 and 4 (7-8 year olds); and Part 3 for Classes 5 and 6 (ages 9-10+). See Primary Sources at end of article. 
One way of making these lessons in good character more memorable is tying them to familiar figures in history whose greatness only comes about because they were good little children. For example, the heroine, Annie McQuaid, is a "quiet little girl with retiring manners" [1908/3/9/p. 268]. Joan of Arc is introduced as: "a good and kind girl ... So kind was she to birds and beasts that they would come when she called them, and feed out of her hands" [1909/3/2/p. 23]. Queen Victoria herself is portrayed as an obedient and hardworking child:

She must obey her teachers-

No better child was seen;

And when she ruled the country,

Was never better queen. [1909/1/4, p. 57]

Allied to being good is being dutiful. Children are introduced to the part they should play in maintaining the greatness of the British Empire:

England expects, and, indeed, knows, that every man will do his duty. But the doing of duty begins with the boy and the girl, and when young we must all train ourselves and fit ourselves for the great duties and responsibilities which will fall upon us when we grow up. [1909/3/4/p. 101]

After goodness, obedience, and duty, comes bravery. Even very young children can be dutiful citizens by being brave and helping others. Children get to read about "The brave fisher lad" [1907/1/2] who saves eight people from a shipwreck; or "Some brave New Zealand girls and boys", including Mamae Rangitahua and Ita Pokiha, who save a girl from drowning [1911/3/5]. In "A brave little lad", Richard Clough, aged 7, saves his home from burning down and the lives of his brother and sister [1911/1/5]. The story ends: "How proud of him everybody was when it was seen what a brave boy he had been" (p. 74).

Brave and dutiful citizens are also prepared to sacrifice themselves for others, their nation, and the Empire. This sacrifice is called the "golden deed" [1914/3/1]. In the 1910 article "What makes a nation great?" children are given summaries of people they should emulate: New Zealand's Grace Darling, Julia Martin, who put herself at great risk to save the lives of a shipwrecked crew; a bugler boy who sounded the alarm to warn of a Mãori 
raid, "determined to do his duty at any cost" (p. 58); and countless more "men and women who risk their lives for others in bush-fires, mining accidents, and when people are in danger of drowning" [1910/2/4/p. 58].

One story that appears multiple times and integrates the themes of goodness, duty, and self-sacrifice is that of Florence Nightingale. Young Florence is praised for her service to others: "It was wonderful to see this bright girl, who might have spent her time in games and sports, giving herself with delight to nursing the sick people of the village" [1910/2/9/p. 120]. She is later recognised for her work in the Crimean War, which brought glory to the Empire: "But all these honours were as nothing to Florence Nightingale. Her noble self-sacrifice was to her only the performance of a simple duty" (p. 133).

\section{The British Empire and imperial duty}

From the first issue, children are regularly reminded that New Zealand is a member of the British Empire and that is where their duty lies. In 1910 they are told: "But New Zealand by itself is not a nation; it is only a part of the largest Empire in the world—-the British Empire" [1910/1/4/p. 59]. In several issues, the "boys and girls of the Empire" are directly addressed by the Earl of Meath:

May you bear in mind that, of the allied peoples of this Empire, each one looks to the others for practical sympathy, protection, and co-operation; and that not only the State to which you belong, but also the Empire itself, looks to you to be ready in time of need, to think, to labour, and to bear hardships in its behalf. ... and thus by your own individual action aid in elevating the British character, strengthening the British Empire, and consolidating the British Race! [1914/3/5/pp. 132-133]

Every year there is a special section to celebrate Empire Day. Children are told about Empire Day and its origins [1912/3/5]; New Zealand's place in the Empire [1914/2/5]; and New Zealand's responsibilities [1909/3/4]. Children are told, "you are given this holiday in order to celebrate with rejoicings the birthday of our late noble and illustrious Queen Victoria, who did so much to build up and consolidate our present great British Empire" [1907/3/1/p. 22]. 
Stories of Queen Victoria, King Edward VII, and King George V are regularly told and re-told, especially in the Empire Day issues. King George V is the "Sailor Prince". Children learn of George's work ethic when he joins the navy at age 12 and does his duty as expected. He later embarks upon a tour of the Empire, to become "acquainted with the British dominions beyond the seas" [1910/3/5/p. 145]. When King George is crowned, a Part 3 journal dedicates over 20 pages to his coronation, the history of coronations, and stirringly patriotic poetry [1911/3/5].

These stories are supplemented by tales of earlier English kings, especially Alfred the Great, whose story was a regular feature across the years and school levels. Children are also introduced to the patron saints, St George, St Patrick, and St Andrew [1910/1/4] along with great British sailors, commanders and adventurers:

... all the bold men who took the flag of England into unknown seas and lands—of Sir Humphrey Gilbert and Raleigh, of Hawkins and Drake, of Frobisher and Davis, of John Smith and William Penn, of Clive and Wolfe, of Anson and Captain Cook, of David Livingstone and Cecil Rhodes, and of a hundred others. [1912/3/5/p. 102]

In 1911, children are told how they, as "boys and girls of New Zealand can help the Empire":

Even in the weakest nations will be found individuals capable of the greatest self-sacrifice and heroism; but the strength of a nation as a whole depends upon the self-reliance, self-respect, and self-sacrifice of the people as a whole. [1911/3/5/p. 154]

The role that they were expected to play was frequently reinforced in poetry as well as prose:

Children of the Empire, you are brothers all;

Children of the Empire, answer to the call ...

Children of the Empire, your fathers fought and died

That you might stand, a noble band, in honour and in pride. [1910/1/4/p. 64] 


\section{The valorisation of war}

From the very first issue of the School Journal, war is presented as a regular feature of history. It appears as commonplace-all nations go to war. Whether it is the Boers against the British, the Spanish against the Dutch, the Swedes against the Danes, the Poles against the Russians, or the Romans against the Gauls, war appears as an adventure-an opportunity to test one's bravery and to return home as a hero or die bathed in glory:

There is death in defeat

That shows far nobler than victorious life ...

But honour, too, to those whose crowns are clenched

In death-stark hands, with high heart's life-blood drenched.

[1907/3/1/p. 11]

Stories of valiant soldiers appear regularly, such as in "Heroes of War" [1912/2/5] which tells the story of several Victoria Cross winners. When another Victoria Cross winner, Field-Marshal Earl Roberts dies in 1914, "Many of his old soldiers wept like children, for Lord Roberts was more than a brilliant commander-he was the soldier's friend, and the model of all a Christian warrior should be" [1915/3/1/p. 2]. Such stories are often placed side by side with children's poems. The following poem is accompanied by an illustration of children playing at war:

And now we're marching onward

In all our brave array-

On to the field of battle-

To conquer, not to slay. [1908/1/4/p. 58]

To ensure that children make personal connections with war, they are introduced to boys and girls of their own age, who display bravery in times of war, even to the death. Stories are selected to show that anyone can step up and play their part. "The Little Bugler" is asked to play a happy tune by the Russians but instead he sounds the alarm. He saves the city but sacrifices his life [1911/1/8]. "Hans the Cripple" [1914/1/2] also saves his village. When soldiers neglect their post, Hans alerts the village of a French raid. He is shot but before he dies he gives thanks to God that he has been able to do "something useful" for his country (p. 27). 
Boys as enlisted soldiers also appear in stories. "Brave Bugler Dunn" is a true story set in the Boer War. Described as "a mere boy with the heart of a man" [1911/2/1/p. 2], Dunn, a 14-year-old boy in the British army, is wounded crossing a river under heavy fire. As children, boys especially, immerse themselves in the heroic deeds of others; they are told how they can be ready to answer the call when it comes. In the poem "Boy Wanted" [1910/2/7/p. 112] the writer seeks "a boy that is manly" and in "The Boys who are Wanted" [1912/2/1/p. 16], boys are exhorted to be strong, smart, and ready to do their duty:

Boys of spirit, boys of will,

Boys of muscle, brain, and power,

Boys to work with all their skill-

These are wanted every hour.

Joining the School Cadets was an immediate action that demonstrated a boy's willingness to be ready. In early issues of the School Journal, school cadet regiments were listed on the final page and recognised for their skills with rifles or drills. One article features numerous photographs of the 13,000 cadets who turned out for Lord Kitchener's 1910 visit to New Zealand [1910/3/3]; another features a report of the senior cadets who went to the Exhibition in Toronto, Canada [1913/3/1].

\section{Part 2-World War 1 and beyond: Creating and perpetuating myths of war}

This section highlights four themes. First, it introduces a theme that appears in pre-war issues but strengthens as the war proceeds - that of the mixing of fact and fiction through the use of myth and legend. We then discuss New Zealand's entry into the war, in particular, the Gallipoli campaign, before concluding with the way in which the war, and New Zealand's part in it, is romanticised and mythologised in the decade following the end of the war.

\section{Myth building}

In the lead up to the war, stories of heroes, myths, legends, and epic odysseys are regular fare in the School Journal. Soldiers of the Roman Empire are represented as courageous, steadfast, and dutiful in the face of mortal danger,

\section{Curriculum Matters 14: 2018}


such as in the illustration of the unflinching Roman sentry, "Faithful unto Death" [1910/2/7/p. 107]. In "The Brave Standard Bearer" a young soldier is pictured fearlessly leaping into battle holding the Roman Eagle aloft [1911/1/7]. Children are also introduced to heroes of old, such as Alexander the Great [1913/1/8]. In "Heroes of European History: Alexander the Great" [1913/3/7] history is linked to mythology as Alexander's ambition is described as being influenced by the stories of Greek legends and heroes.

Stories of places and people from antiquity, such as "Jason and the Golden Fleece" [1910/3/10] reinforce the themes of courage, daring, and adventure. In a strange analogy that attempts to link mythology to the children's present day, an article describes the export of New Zealand wool fleeces in a similar heroic vein. The photograph of a steamship in Lyttelton Harbour becomes an "argosy" bathed in golden light: "As the man on the wharf watched the disappearing steamship, a golden haze surrounded her. She was bearing on its precious voyage the Golden Fleece" [1910/3/3/p. 92].

The stories of sailors and adventures of old also connect to New Zealand as a seafaring nation. When the battleship HMS New Zealand is commissioned by the New Zealand Government and gifted to the Empire in 1913, the School Journal celebrates this feat with multiple stories and photographs [1913/2/4; 1913/3/4]. Before leaving the country, the ship tours New Zealand and one article proudly acclaims, "New Zealand thus showed that she was prepared to bear her full share of the burden of empire so long as war is the arbiter of nations" [1913/3/4/p. 101].

\section{New Zealand enters the war}

By the outbreak of war, there was an increasing sense of an emerging national identity but it was still blended with continuing pride in New Zealand's place in the Empire—and an expectation "that you might do the thing you will—and strike with the arm of might—For justice and for freedom's sake—for Country, King and Right" [1910/1/4/p. 64].

One of New Zealand's first military acts was to "capture" Western Samoa from the Germans [1914/3/9]. Post-capture pomp and ceremony include the raising of the Union Jack amidst military spectacle. Photographs of the occasion and detailed reporting of the event is described as "what, in a sense, 
may be termed New Zealand's first overseas conquest" (p. 280).

As men sign up and ship out, children read the speech given to the troops by New Zealand Defence Force Commander, Sir Alexander Godley. The address makes it clear that being a soldier from New Zealand means representing, not only your country and your regiment, but being more than equal to the soldiers of the British Army: "Remember that the whole of New Zealand will be watching you, and will expect to see ... something more than ordinary from the men who are here to-day" [1914/3/9/pp. 272-273].

Civilians are also answering the call. The School Journal tells of nurses, doctors, and ambulance drivers risking their lives to transport the wounded to safety, then working without rest to ease their suffering [1914/3/9]. These stories continue the theme of civilian sacrifices, highlighted in earlier journals by exemplary figures such as Florence Nightingale.

In turn, links are made to the children themselves. The children of New Zealand raised $£ 2,289$ for wartime motorised ambulances to be sent to Egypt, the destination for war-wounded. One article shows a full-page spread of a picture of the ambulances [1916/3/7/pp. 208-209]. The children are also thanked by British Prime Minister Asquith for their contributions, which are "a fitting way for children to help the Empire" [1914/3/9 p. 259].

\section{The Gallipoli campaign}

In hindsight, we can see the Gallipoli campaign for what it was-a lost battle in a much larger war (Carlyon, 2011; King, 2007; Macleod, 2004; Pugsley, 1990). In New Zealand and Australia, however, it found its way into national mythology. This is, in part due to strong public expectation of how the soldiers would perform, the selective nature of army dispatches, and the way the campaign was recorded and disseminated through the media of the day (Macleod, 2004; Midford, 2012) —and this includes the School Journal. The Gallipoli campaign was reported at length in the School Journal. The message that "Australians and New Zealanders amazed the whole world by their heroic gallantry at Gallipoli" [1916/3/5/p. 137] was to become embedded in the consciousness of both nations with a sacred reverence (King, 2007; Midford, 2012). Maps connected ancient place names and legends of the past with the contemporary battles on the peninsula:

\section{Curriculum Matters 14: 2018}


It was across the Dardanelles, then called the Hellespont, that the Persian ruler Xerxes built his famous bridge of boats when he invaded Greece, and was so bravely opposed by Leonidas and his three hundred gallant Spartans, and at the same place, a century and a half later, Alexander the Great took his army across when he invaded Asia, and marched as far as India. To-day, with the warships of the Allies bombarding and destroying the forts along the banks of the Dardanelles, this narrow strait springs again into historical importance. [1915/3/3/p. 2]

Stories are told of soldiers who are brave, loyal, and resourceful, such as Corporal Bassett, a New Zealander, who received the Victoria Cross for bravery at Gallipoli [1916/3/5]. Stirring poems are written by those at home; for example, "J. Mitchell of Oamaru" [1916/3/5/p. 154] writes:

Anzac, laved by Aegean tide,

Where our sons have bled and died,

Giving to land a new-born name,

Gaining glory and deathless fame.

While the losses are horrific, they are not reported as such in the School Journal, instead poetry and prose glorify war and loss. A drawing of crosslinked New Zealand and Australian flags crowned with an ancient victory laurel appears at the head of an Anzac poem illustrating the growing awareness of the two countries linked both to the classical world and in contemporary comradeship [1916/3/5]. Intertwined with ancient myths, the legend of Gallipoli coalesces to create a new myth of the heroic Anzac soldier (Midford, 2012; Seal, 2007). The first remembrance of the ill-fated landing at Anzac Cove takes place when the news reaches home. Flags are flown at half-mast and families scan the casualty lists. Yet, the defeat is cast in heroic terms:

Why do you grieve for us who lie

At our lordly ease by the Dardanelles?

We have no need for tears or sighs,

We who passed in the heat of fight

Into the soft Elysian light ... [1916/3/5/p. 129] 


\section{Celebration and commemoration}

In 1916, a half-day holiday is declared for April 25 and commemorative services are held in New Zealand and in Westminster Abbey in London. In the 1918 Empire Day School Journal issue, children are told, "The history of your Empire, from August, 1914, to this day, has been written in the blood of my immortal sons. It is a book of golden deeds" [1918/3/5/p. 129]. Defeat in battle was portrayed as an example of bravery and sacrifice for the greater good of the Empire:

Sunday the 25th April is the fifth anniversary of the landing at Gallipolithat feat of arms which for dauntless bravery has never been equalled, and which proved the loyalty of the sons of the far-off dominions to the Motherland. [1920/3/3/p. 82]

In 1919, however, the focus moves instead to Armistice Day and the unveiling of the national cenotaph in Wellington. In the School Journal, the words of the officiating padre were reiterated, pointing out that the letters A.N.Z.A.C. stand for daring, endurance, brotherhood, courage, sacrifice, and emulation. Evergreen wreaths, cut flowers, and crosses made by children are placed on the cenotaph and Karori cemetery in memory of soldiers cut off in the flower of their youth [1920/3/3]. In the early 1920s, Anzac Day becomes an official public holiday. In a mix of national pride and mourning, the sacrifices, bravery, and stoicism of the Anzac soldiers are revered in collections of stories, photographs, and poems. In "Heroes in Gallipoli" [1925/2/3], their sacrifice is remembered:

It is with both pride and sorrow that we honour the memory of such men, they willingly suffered pain and misery, and even death itself, in order to save their country. Their glory will never be dimmed, and for all time-At the going down of the sun, and in the morning, we will remember them.

Some accounts are highly romanticised. Several articles are based on British poet laureate John Masefield's embellished narratives connecting to Greek myths set in the same location [1926/2/3; 1930/3/3]. An Anzac Day School Journal article in this vein describes the Gallipoli landing as follows:

No such gathering of fine ships has ever been seen upon this earth, and the beauty and the exultation of the youth upon them made them like sacred things as they moved away ... The men went like kings in a pageant to the imminent death. [1920/3/3/p. 84] 
Yearly commemorations become a feature in the School Journal. Stories with titles such as "A Great and Terrible Day" [1926/2/3] and "A Land of Valour" [1927/3/3] tell of the soldiers living a simple life on an inhospitable hillside, enduring privations with stoic resilience, dutifully serving their country and the Empire. Photographs of harsh living conditions are designed to impress upon school children the steadfastness and endurance of the Anzac soldiers at Gallipoli. These portrayals continue well after the defeat and terrible losses of life are made known.

In 1927, the School Journal reprints a poem by Canadian doctor, John McCrae, recalling the poppies of Flanders Fields [1927/3/3]. This symbol is then linked to the poppies that grew on the hillsides at Gallipoli. In this way, the beginning of an association between Anzac Day and the remembrance poppies is initiated.

It is not until 1929 that the real consequences of the war are raised in the School Journal. In the April issue [1929/3/3], in an article about the League of Nations, the writer says: "The cost of that war-the Great War of 1914-18was gigantic, not only in money, but in human lives ... War, like famine, disease, and fire, is a scourge to all humanity" (p. 90) ... that leaves behind it nothing but a huge record of death, destruction, and desolation" (p. 86). Militarism is finally seen for what it is: "If a country is trained to believe in war, to prepare for war, and to use war as a means of enforcing its opinions, it must inevitably become warlike in feeling" (p. 88).

\section{Discussion}

This discussion will focus on three themes-preparing children to become citizens of the Empire; the place of Gallipoli in the forging of a new New Zealand identity; and the role of the School Journal in myth-making for political indoctrination.

\section{Preparing children to become citizens of the Empire}

The evidence is clear that most of the content of early School Journals is moralistic, imperialistic, and militaristic. Children, from the time they entered school, were exhorted to be good, kind, and obedient. They were introduced to characters in fiction and nonfiction who had been good or, 
alternately, were shunned because they were lazy or naughty. Children were given the clear message that the famous and heroic figures they were expected to emulate were always good, kind, and hardworking as children. While this didactic approach to moral education was typical of Victorian children's literature (Patrick, 2009), the messages in School Journal went beyond generic goodness to goodness for the sake of the Empire. Goodness was equated with courage and bravery —and the highest level of goodness was the "golden deed" or self-sacrifice. Children read about boys and girls who sacrificed themselves for others, their country, and for the Empire. And the message was clear - that any child could do this—-boy or girl, able-bodied or not, military-minded or not. The call could come at any time and children needed to be ready. Stories of brave children were accompanied by stories of brave adults and great adventures-leaders, discoverers, soldiers, sailors, nurses, kings, and queens. Again, the message was that goodness, obedience, and courage were the ways in which children could do their duty, as these role models had done, for the sake of others, their nation and, of course, the Empire. As the highest form of duty was self-sacrifice- the "golden deed"- this concept was directly associated with the greatness and glory of war, especially wars in which Britain (or England) had been the victor. But important messages were also given that to lose in pursuit of victory for your country or the Empire was just as glorious. Win or lose, your sacrifice would live on in history as "deathless fame".

These moral, imperial, and military messages appeared across all types of contributions, from illustrations of flags, maps of voyages, photographs of real people, to children's and adult poems, nonfiction accounts, letters, fiction stories, myths, and legends. Many contributions appeared in a simpler form in a junior-level journal and in a more sophisticated manner in a senior journal in the same issue. Popular items were repeated across the years and links between items in the same year or journal also reinforced the messages being imprinted on children's impressionable minds.

\section{The School Journals role in perpetuating the myth of Gallipoli forging a new New Zealand identity}

A mix of heroic figures, real and imaginary, actual historical events, and ancient myths and legends was used simultaneously to reinforce the moral, 
imperial, and military messages described earlier. The fact that the Gallipoli campaign took place in the same location as many of these tales cemented the links between antiquity and Gallipoli (Midford, 2012; Seal, 2007). That the campaign was a disaster, ineptly managed by the British and causing unnecessary loss of life, needed to be sidestepped, and was, therefore, couched in terms that were palatable to those back home. Telling the story as one of heroic deeds against immeasurable odds fitted with the mythological setting and elevated the dead to sacred beings (King, 2007; Midford, 2012; Seal, 2007). Hynes (1999) defines a myth in this context as a "dramatized story that has evolved in our society to contain the meanings of the war that we can tolerate" (p. 207). When the horrific losses became known, they seemed too terrible to contemplate and the sanitised and mythologised version became easier to hold on to and repeat. And repeated it was, in every School Journal for years to come. The School Journal did not invent these myths but it readily repeated them-from the stoic Anzac, the epitome of New Zealand manhood, dug into a rugged hillside, to the fanciful John Masefield version of the soldiers going to their death like kings in a pageant. Midford (2012) explains that, "Historically, myths are transmitted from generation to generation without anyone knowing who created them ... Over the course of time events come to be remembered in their poetic form rather than their historical form" (p. 67).

It took 10 years before the School Journal acknowledged the horror of World War 1, and, indeed, all wars. Over this time, the myth of the Gallipoli campaign marking the turning point in New Zealand's identity was also established. We noted that, as the 1920s proceeded, the School Journal focused less on celebrations of Empire Day and more on commemorations of Anzac Day. The content talked less about duty to the Empire and more about pride in the nation. While New Zealand was still a member of the Empire, which would later become the Commonwealth, it signed the Treaty of Versailles as an independent nation and joined the League of Nations in its own right (King, 1996). While true nationhood was not officially conferred until 1947, New Zealand was already acting as a self-governing and independent nation (King, 1996; Kundu, 2009).

Did Gallipoli mark the start of New Zealand's new identity? King (1996) claims that the point that marked New Zealand's beginning as an individual 
entity came earlier when New Zealand sent troops to the Boer War. He does agree with other writers (such as Carlyon, 2011; Eldred-Grigg, 2010; Phillips, 1996; Pugsley, 1990) that the Gallipoli campaign and later battles in Europe consolidated the separation of national identity from imperial identity, in part due to the catastrophic losses and diminishing respect for British military leadership.

And what was the School Journals role in perpetuating the myth that the Gallipoli campaign was the beginning of a new national identity? The School Journal was supplied free to every child in state-funded schools and from 1914 was compulsory reading. As the Department of Education's only resource provided to schools at the time, it became the main curriculum resource, especially in relation to history and civics, and, if there had been such a subject at the time, current events. Because of the extensive coverage it gave to the Gallipoli campaign, which was far more than any other event in World War 1, and because the items were read every year, in the classroom and again at home, we can surmise that the School Journal did play a role in promoting and sustaining both the story of Gallipoli and its role in forging a distinct New Zealand identity.

\section{The School Journal and myth-making curriculum for political indoctrination}

Using educational materials to reinforce social mores and for political indoctrination is not a new concept (Foster \& Crawford, 2006; Kridel, 2013). When social forces and political ambition align, particular messages appear as unified and unproblematic. Matusevich (2006) claims that powerful figures with an ideological agenda believe that curriculum resources can impact children's minds and that children are gullible and easily influenced. Matusevich (2006) also claims that curriculum resources, such as textbooks, when widely used, become the de facto curriculum, taking the place of the official curriculum.

At the time of World War 1, the School Journal was infused with ideological aims that were social, militaristic, and political. The rise of imperialistic rhetoric, espoused by organisations such as the Victoria League, the League of Empire, and the Boy Scouts promoted social conformity to a particular way of thinking and acting — and the link to influencing young minds was 
a clear objective (Bush, 2000, Hucker, 1979; Stephenson, 2010). Outside school, Empire was also tied to Christianity, particularly Protestantism (Morrison, 2011). As the 1877 Education Act established schools as secular institutions, religious organisations responded to the perceived need to teach religious and moral instruction (Morrison, 2011, 2015). The 1911 census showed that $70 \%$ of children attended Sunday Schools (Troughton, 2004), which were active in promoting the Empire and the war effort (Morrison, 2011). Other organisations such as the National Defence League, the Navy League, and School Cadets promoted militaristic thinking under the guise of defending the nation and the Empire (Bennett, 2012; Hucker, 1979).

These social, imperial, and militaristic ideals aligned with the beliefs of politicians and education officials of the time, such as Prime Ministers, Sir Joseph Ward and William Massey along with Inspectors-General of Schools, George Hogben, CJ Parr and TB Strong (King, 1996; Malone, 1973). Hogben, himself, according to Malone (1973), was the author of some of the items in the School Journal. It is interesting that, apart from this claim of Hogben's authorship and also evidence of other authorial attributions in cases of the occasional poem or extract, most items are anonymous. The writers are invisible. This invisibility gives a cloak of credibility. If you cannot ascribe words or ideas to someone, they are more easily accepted as fact, not as someone's opinion or interpretation. Thus, they appear as take-for-granted truths.

Morrison (2011) suggests that, in New Zealand, the notion of Empire was presented to children "through both secular and religious pedagogy as a set of virtues and values" with the "political, spatial, commercial, military or cultural" elements (p. 318) being a secondary consideration. Our close reading of hundreds of items in the School Journal between 1907 and 1930 would suggest a slightly different emphasis, that there was a clear intent to instil a political (imperialistic) belief and militaristic mind-set in the minds of school children. This finding is supported by researchers who have examined the words and actions of children of the time through their oral and written accounts. Bennett (2012) and Graham (2008) highlight the numerous ways in which the adult world sought to influence children's wartime beliefs and behaviours through lessons, patriotic magazines, public lectures, certificates, fundraising, and concerts. Bennett notes that schools "carefully taught 
selected pieces of information about the Great War" (2012, p. 22). Graham comments on the School Journal, in particular, "With its contents carefully crafted ... the Journal made good use of photographs and commentary ... to emphasise the connection between youthful patriotic endeavour and the beneficial outcomes for soldiers abroad" (2008, p. 435). There is some evidence that the patriotic rhetoric, what Bennett calls "war-talk", did make an impact on the "substantive majority" (Bennett, 2012, p. 20; see also, Hucker, 2009), that "children and young people were energetic supporters of the war effort" (Morrison, 2015, p. 86) and that young men, in particular, "asserted that they wanted to become soldiers so they could help fight enemy nations" (Bennett, 2012, p. 83; see also, Hucker, 2009).

Could the School Journal of the time be accused of indoctrination? We feel the evidence shows that the School Journal used focused and repeated messages and mythologising (Midford, 2012; Seal, 2007) along with emotion and imagery (Morrison, 2015) with clear intent to foster ideology (Kridel, 2013) through particular content (Peterson, 2007) to get students to hold beliefs in a nonrational and noncritical manner (Peterson, 2007), despite evidence to the contrary (Snook, 1972) —or, in other words, indoctrination. Importantly, however, Bennett (2012), Graham (2008), and Morrison $(2011,2015)$ note that not all children and young people were passive recipients of the intended lessons. While many were profoundly affected, others remained detached and some were even critical of what they were told. It is important to note that, while our reading of the indoctrinatory intent of the School Journal is clear and unequivocal, the path between the prescribed curriculum and the received curriculum is never as straightforward as curriculum content writers might wish (Kridel, 2013; Mutch, 2009).

\section{Conclusion}

In conclusion, this article reports on the findings of a study that investigated the way in which New Zealand school children of the time were taught about World War 1 through the School Journal, a free, and later compulsory, curriculum resource. The findings show that, prior to the war, children were being prepared for engagement in war through moralistic teaching, social conditioning, imperialistic rhetoric, and militaristic ideals. During the war, the horrific losses, particularly at Gallipoli, were couched in heroic

\section{Curriculum Matters 14: 2018}


and mythological terms, in line with the reporting of the day. While there is some debate as to whether the Gallipoli campaign was the "birth of a nation", it certainly consolidated New Zealand's developing independence from the Empire. Our findings, which confirm and extend those of other historians and researchers, clearly show the intent that the compilers of the School Journal had to influence children's thinking in particular ways. First, prior to World War 1 to build imperial and militaristic sentiments and, later, shaping the Gallipoli myth. These aims were approached through the careful selection and placement of items, repetition of imperialistic and nationalistic rhetoric, collapsing of time and space, and mixing of fact and fiction. This study provides an insightful example of how curricula and their supporting resources can be used for indoctrinatory purposes. It highlights the need for all educators to be vigilant to ways in which curricula have the potential to be used for political indoctrination — and the possible consequences.

\section{Acknowledgements}

This research was made possible by funding from the North Shore Teachers College Trust Fund and The University of Auckland. The authors would also like to thank John Laurie, Librarian at The University of Auckland's central library for his invaluable support.

\section{Primary Sources: School Journal, Year/Part/Number: "Title"}

References to the particular issues are given in the following manner: [Year/ Part/Number/Page(s)]. Part 1 journals were for Classes 1 and 2 (5-6-yearolds); Part 2 for Classes 3 and 4 (7-8-year-olds); and Part 3 for Classes 5 and 6 (ages 9-10+).

School Journal, 1907/1/2: "The Brave Fisher Lad"

School Journal, 1907/1/6: "Do your Best" 
School Journal, 1907/3/1: "Isalwanda" (story and poem)

School Journal, 1908/1/4: "The Band of Red, White and Blue"

School Journal, 1908/3/9: "Annie MacQuaid"

School Journal, 1909/1/4: "Queen Victoria's Promise”

School Journal, 1909/3/2: "Joan of Arc"

School Journal, 1909/3/4: "Britain's Position among the Nations, and the Responsibilities of her Citizens"

School Journal, 1910/1/4: "Children of the Empire"

School Journal, 1910/2/4: "What Makes a Nation Great?"

School Journal, 1910/2/7: "Heroes of other lands"

School Journal, 1910/2/7: "Boy Wanted"

School Journal, 1910/2/9: "Florence Nightingale"

School Journal, 1910/3/3: "Lord Kitchener's Visit and Message"

School Journal, 1910/3/3: "The Golden Fleece"

School Journal, 1910/3/5: "King George V: The Sailor Prince"

School Journal, 1910/3/10: "Building of the Argo"

School Journal, 1911/1/5: "A Brave Little Lad"

School Journal, 1911/1/7: "The Story of the Brave Standard Bearer"

School Journal, 1911/1/8: "The Little Bugler"

School Journal, 1911/2/1: "Brave Bugler Dunn"

School Journal, 1911/3/5: "How Boys and Girls of New Zealand can help the Empire"

School Journal, 1911/3/5: "Some Brave New Zealand Boys and Girls"

School Journal, 1911/3/5: The Coronation of King George V and Queen Mary"

School Journal, 1912/2/1: The Boys who are Wanted"

School Journal, 1912/2/5: "Heroes of War"

School Journal, 1912/3/5: "Empire Day"

School Journal, 1913/1/8: "Alexander the Great"

School Journal, 1913/3/7: "Heroes of European History: Alexander the Great"

School Journal, 1913/3/1: "New Zealand Cadets in Canada"

School Journal, 1913/2/4: "The New Zealand"

School Journal, 1913/3/4: "HMS New Zealand"

School Journal, 1914/1/2: "Hans the Cripple"

School Journal, 1914/2/5: "How New Zealand became Part of the British Empire"

School Journal, 1914/3/1: "What is a Golden Deed?"

School Journal, 1914/3/5: "The Story of Empire Day"

School Journal, 1914/3/9: "The Capture of German Samoa by the New Zealand Expeditionary Force" 
School Journal, 1914/3/9: "Sir Alexander Godley's Address to the New Zealand Troops" School Journal, 1914/3/9: "The Red Cross on the Battlefield"

School Journal, 1915/3/1: "The Story of Earl Roberts"

School Journal, 1915/3/3: "The Dardanelles"

School Journal, 1916/3/5: "To the Women they have Left: The Dead at Anzac"

School Journal, 1916/3/5: "New Zealand Children's Motor Ambulances at the Front"

School Journal, 1916/3/5: "At Anzac in a Hospital Ship"

School Journal, 1916/3/5: "Australia and New Zealand United"

School Journal, 1918/3/5: "Empire Day"

School Journal, 1920/3/3: "Anzac Day"

School Journal, 1925/2/3: "Heroes in Gallipoli"

School Journal, 1926/2/3: "A Great and Terrible Day"

School Journal, 1927/3/3: "A Land of Valour"

School Journal, 1927/3/3: "The League of Nations: 1. Drifting into War"

School Journal, 1930/3/3: "The Landing at Gallipoli"

\section{References}

Apple, M. (1979). Ideology and curriculum. New York, NY: RoutledgeFalmer.

Bennett, C. (2012). Now the war is over, we have something else to worry us.": New Zealand children's responses to crises 1914-1918. Unpublished master's thesis, Victoria University of Wellington.

Bingham, R. (2017). The "making of a soldier": Masculinity and soldierhood as portrayed in the New Zealand School Journal, 1907-1925. Citizenship, Social and Economics Education, 16(3), 174-183. https://doi.org/10.1177/2047173417740715

Burdman, D. (2003). Education, indoctrination, and incitement: Palestinian children on their way to martyrdom. Terrorism and Political Violence, 15(1), 96-123. https://doi. org/10.1080/09546550312331292977

Bush, J. (2000). Edwardian ladies and imperial power. London; New York: Leicester University Press.

Callan, E., \& Arena, D. (2009). Indoctrination. In H. Siegel (Ed.), The Oxford handbook of philosophy of education. New York, NY: Oxford University Press.

Carlyon, L. (2001/2011). Gallipoli. Sydney: Pan Macmillan Australia.

Eldred-Grigg, S. (2010). The great wrong war: New Zealand society in WWI. Auckland: Random House.

Ewing, J. (1970). The development of the New Zealand primary school curriculum 18771970. Wellington: New Zealand Council for Educational Research.

Foster, S., \& Crawford, K. (Eds.). (2006). What shall we tell the children? International perspectives on school history textbooks. Greenwich, CT: Information Age Publishing. 
Graham, J. (2008). Young New Zealanders and the Great War: Exploring the impact and legacy of the First World War, 1914-2014. Paedagogica Historica, 44(4), 429-444. https://doi.org/10.1080/00309230802218306

Hucker, G. (1979). When the Empire calls: Patriotic organisations in New Zealand during the Great War. Unpublished master's thesis, Massey University, Palmerston North.

Hucker, G. (2009). The great wave of enthusiasm. New Zealand Journal of History, 43(1), 59-75.

Hynes, S. (1999). Personal narratives and commemoration. In J. M. Winter \& E. Sivan (Eds.), War and remembrance in the twentieth century (pp. 205-220). Cambridge, UK: Cambridge University Press. https://doi.org/10.1017/CBO9780511599644.012

King, M. (1996). The Penguin history of New Zealand illustrated. Auckland: Penguin.

Kridel, C. (2013). Instruction, indoctrination, imposition: Conceptions of propaganda in the field of education. In J. Auerbach \& R. Castronovo (Eds.), The Oxford handbook of propaganda studies (pp. 163-179). New York, NY: Oxford University Press. https:// doi.org/10.1093/oxfordhb/9780199764419.013.008

Kundu, A. (2009). To what extent was New Zealand "Born as a Nation" in World War I? http://www.firstworldwar.com/features/newzealandnationhood.htm.

Lall, M. (2008). Educate to hate: The use of education in the creation of antagonistic national identities in India and Pakistan. Compare, 38(1), 103-119. https://doi. org/10.1080/03057920701467834

Lee, D. (2010). Portrayals of non-North Koreans in North Korean textbooks and the formation of national identity. Asian Studies Review, 34(3), 349-369. https://doi.org/ 10.1080/10357823.2010.507865

Macleod, J. (2004). Reconsidering Gallipoli. Manchester: Manchester University Press. https://doi.org/10.4324/9780203489314

Mahamud, K. (2016). Emotional indoctrination through sentimental narrative in Spanish primary education textbooks during the Franco dictatorship (1939-1959). History of Education, 45(5), 653-678. https://doi.org/10.1080/0046760X.2015.1101168

Malone, E. P. (1973). The New Zealand School Journal and the imperial ideology. New Zealand Journal of History, 7(1), 12-27.

Matusevich, M. (2006). Strange bedfellows: Censorship and history textbooks. Social Studies Research and Practice, 1(3), 359-373.

Midford, S. (2012). Constructing the 'Australian Iliad': Ancient heroes and Anzac diggers in the Dardanelles. Melbourne Historical Journal, 39(1), 59.

Morrison, H. (2011). "Little vessels" or "little soldiers": New Zealand Protestant children, foreign missions, religious pedagogy and empire, c.1880s-1930s. Paedagogica Historica, 47(3), 303-321. https://doi.org/10.1080/00309230.2010.493160

Morrison, H. (2015). Settler childhood, Protestant Christianity and emotions in colonial New Zealand, 1880s-1920s. In S. Olsen (Ed.), Childhood, youth and emotions in 
modern history. National, colonial and global perspectives (pp.76-94). Houndmills, Basingstoke, UK: Palgrave Macmillan. https://doi.org/10.1057/9781137484840_5

Mutch, C. (2009). Curriculum: What, how and for whom? Curriculum Matters, 5, 1-5.

Mutch, C. (2017). In the footsteps of the Anzacs: Teaching about war, yesterday and today. Citizenship, Social and Economics Education, 16(3), 145-147. https://doi. org/10.1177/2047173417736904

Mutch, C., \& Cameron-Lewis, V. (2017). Teaching about war today: An analysis of curriculum resources produced for New Zealand's commemoration of the First World War. Citizenship, Social and Economics Education, 16(3), 184-198. https://doi. org/10.1177/2047173417745872

Nelson, T. (2015). History as ideology: The portrayal of Stalinism and the great patriotic war in contemporary Russian high school textbooks. Post-Soviet Affairs, 31(1), 37-65. https://doi.org/10.1080/1060586X.2014.942542

O'Brien, G. (2007). A nest of singing birds: 100 years of the New Zealand School Journal. Wellington: Learning Media.

Patrick, R. (2009). Teaching the storied past: History in New Zealand primary schools 19001940. Unpublished master's thesis, University of Melbourne.

Perreau, M., \& Kingsbury, L. (2017). The Anzac Iliad: Early New Zealand School Journals and the development of the citizen-child in the new dominion. Citizenship, Social and Economics Education, 16(3), 157-173. https://doi.org/10.1177/2047173417743032

Peterson, B. (2007). Holding teachers accountable for indoctrination: A reexamination of I. A. Snook's notion of "intent". Philosophy of Education Archive, 298-305.

Phillips, J. (1996). A man's country? The image of the Pakeha male—A history. Auckland: Penguin.

Pinar. W., Reynolds, W., Slattery, P., \& Taubman, P. (1995). Understanding curriculum. An introduction to the study of historical and contemporary curriculum discourses. New York: Peter Lang.

Pugsley, C. (1990). Gallipoli: The New Zealand story (2nd ed.). Auckland: Sceptre/Hodder and Stoughton.

Seal, G. (2007). ANZAC: The sacred in the secular. JAS: Australia's Public Intellectual Forum, 91, 135-144.

Snook, I. (1972). Indoctrination and moral responsibility. In I. Snook (Ed.), Concepts of indoctrination (pp. 152-161). London, UK: Routledge and Kegan Paul.

Stephenson, M. (2010). Learning about empire and the imperial education conferences in the early twentieth century: Creating cohesion or demonstrating difference? History of Education Review, 39(2), 24-35. https://doi.org/10.1108/08198691201000007

Troughton, G. (2004). Religious education and the rise of psychological childhood in New Zealand. History of Education Review, 33(2), 30-44. https://doi. org/10.1108/08198691200400008 
Mutch, Bingham, Kingsbury, and Perreau

\section{The authors}

Carol Mutch is an associate professor in the School of Critical Studies in Education in the Faculty of Education at The University of Auckland. At the time of conducting this research, Maria Perreau was a doctoral candidate and research assistant in the School of Critical Studies in Education, while Rosemary Bingham and Lynette Kingsbury were University of Auckland Summer Scholars. All collaborated on the Teaching About War: Yesterday and Today project.

Email: c.mutch@auckland.ac.nz 